Available Online : https://proceeding.researchsynergypress.com/index.php/cset/index

RSF Conference Series: Engineering and Technology

ISSN 2809-6843 (Online) | 2809-6878 (Print)

Volume 1 Number 1 (2021): 248-267

\title{
Evaluation of Mud Weight Using Safe Mud Window Concept Based on Well Log Data: A Case Study of Well OP-002 in the North Sumatra Basin Area, Indonesia
}

\author{
Aris Buntoro1', Basuki Rahmad², Allen Haryanto Lukmana' ${ }^{3}$, Dewi Asmorowati ${ }^{4}$ \\ 1, 3, 4Petroleum Engineering Department, UPN "Veteran" Yogyakarta, Indonesia \\ ${ }^{2}$ Geological Engineering Department, UPN "Veteran" Yogyakarta, Indonesia
}

\begin{abstract}
In the drilling operation of well OP-002 which is located in the North Sumatra Basin at a depth interval of 2887 - $3186 \mathrm{~m}$ occurred partial loss, and caving at a depth interval of $500-1650 \mathrm{~m}$, where the drilling problem is caused by the use of inappropriate mud weight. Safe mud window analysis is carried out by processing well log data to build PPFG (Pore Pressure Fracture Gradient) and 1D Geomechanics model using several calculation methods. Furthermore, the results of the calculation of pore pressure and fracture gradient are validated with well test data from the well OP-002, so the safe mud window can be determined, and can be used as a basis in the analysis of the drilling problems that occur. The optimum mud weight can minimize wellbore instability, with a limit value that must be greater than the collapse pressure, but not exceeding the minimum insitu stress limit. From the results of the mud safe window analysis, it can be concluded that at a depth interval of 500 - $1650 \mathrm{~m}$ caving occurs, because the density value used is smaller than the shear failure gradient, and at a depth interval of $1619-2829 \mathrm{~m}$, the density value used is greater than Shmin. To overcome this problem, a mud wight with a safe mud window concept is recommended, namely the selection of the optimum mud weight to be used must be greater than the pore pressure and shear failure gradient and does not exceed the minimum horizontal stress and fracture gradient values.
\end{abstract}

Keywords: Mud Weight, Safe Mud Window, Well Log

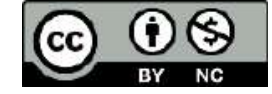

This is an open access article under the CC-BY-NClicense

\section{INTRODUCTION}

Precise and optimal mud weight planning in drilling operations is very necessary because one of the functions of drilling fluids is to control the pore pressure. In addition, proper mud weight planning can avoid drilling problems that cause an increase in the value of NPT (Non-Productive Time). One of the drilling problems is due to the planning of the mud weight that is not optimal which causes the instability of the borehole which is characterized by the formation of a cave on the borehole wall.

In planning the mud weight, several parameters must be considered, including the mechanical properties of the rock being penetrated and the pore pressure profile. In general, the mud weight is designed based on the pressure range window, but caving often occurs which causes the pipe stuck. Based on these conditions, the safe mud window concept is used, namely by adding the shear failure gradient parameter in the pressure window.

\section{LITERATURE REVIEW}

Many correlations and models have been developed for the prediction of abnormal pressure of various parameters (Hottman \& Johnson 1965; Matthews \& Kelly 1967; Pennebaker 1968; McClendon 1971; Zamora 1974; Eaton 1975). The method has limitations; for example, some models can only be used in clean shales (Table1). 
Table 1. The pore pressure prediction method can only be used for clean shales (Basuki 2017)

\begin{tabular}{|c|c|c|}
\hline \multicolumn{3}{|c|}{ Pore Pressure } \\
\hline Lithology & Prediction & Measure \\
\hline Sand & x & $\checkmark$ \\
\hline Carbonates & X & $\checkmark$ \\
\hline Shale & $\checkmark$ & $\times$ \\
\hline Salt & X & X \\
\hline
\end{tabular}

Some pore pressure prediction methods only can be applied to the pressure generated by the under-compaction mechanism or some of them do not apply in unloading formations. Therefore, the researchers tried to use AI (Acoustic Impedance) from seismic data to predict pore pressure with good precision. To predict the pore pressure, four input parameters are used, namely: depth, Gamma Ray log, density log, and soniclog.

Some literature show that the parameters used to predict pore pressure from well log data. Most methods require both normal and abnormal trends, to estimate pore pressures.

\section{PPFG and Geopressure Model Prediction Method}

\section{a. Overburden Gradient Prediction Calculation}

The formation overburden stress gradient (OBG) in onshore drilling can be estimated to vary from $1.0-1.1 \mathrm{psi} / \mathrm{ft}(0.0227-0.025 \mathrm{MPa} / \mathrm{m})$. But in this study, OBG was calculated from the density log (RHOB) data. Because the density log data does not start from the surface/seabed, so in some equations, calculation of the pseudo-RHOB shallow section by integrating the LWD / wireline RHOB log data.

\section{b. Pore Pressure (PP) Prediction Calculation}

There are several methods for predicting pore pressure calculations, namely: Equivalent Depth, Eaton's, and Bower's methods.

\section{- Eaton's Method:}

In the prediction of the pore pressure of well OP-002 using Eaton's method, where Eaton's exponent which is matched with the actual MW is 3.5 (Eaton's exp: 3.5). Mathematical equation Eaton's method used:

$$
P P=O B G-(O B G-P P)_{N} \stackrel{\underline{D T_{N}} x}{\left(\underset{D T_{0}}{)}\right)}
$$

where;

$\mathbf{P P}=$ Pore Pressure Gradient (psi/ft or lb/gal),

OBG = Overburdent Gradient (psi/ft orlb/gal),

$\mathbf{P P}_{\mathbf{N}} \quad=$ Normal Pore Pressure Gradient (psi/ft or lb/gal),

DTo = Observed Interval Transit Time $(\mathrm{msec} / \mathrm{m})$,

DT $_{\mathbf{N}} \quad=$ Normal Interval TransitTime $(\mathrm{msec} / \mathrm{m})$,

$\mathbf{x} \quad=$ Eaton Exponent (dimensionless).

\section{- Bower's Method:}


Bower's method uses sonic velocity and empirically determined parameters to determine the vertical effective stress, which is then subtracted from the overburden (vertical total stress) to determine the pore pressure.

This method can be applied to predict the pore pressure caused by compaction disequilibrium or due to some sourcemechanism.

\section{- $\quad$ "Loading" Method}

In the "Loading" method only two empirical parameters are required if the overpressure is caused by compaction disequilibrium "loading".

$$
P P=\frac{\left(\frac{\frac{10^{6}}{D T}-\frac{10^{6}}{D T_{m l}}}{A}\right)^{(1 / B)}}{\text { depth }}
$$

The values of the two empirically determined parameters can be determined in the Compaction Trend Analysis or selected based on experience in offset wells.

\section{- "Unloading" Method}

Further information and additional empirical parameters are required when stress is caused by the source mechanism.

The "Maximum velocity depth" parameter, $\boldsymbol{d}_{\boldsymbol{m a x}}$ controls whether "Unloading" has occurred or not. If $\boldsymbol{d}_{\max v}>$ depth, "Unloading" has not occurred. If $\boldsymbol{d}_{\boldsymbol{m a x} v}<$ depth then the assumed "Unloading" behavior of pore pressure is calculated as follows:

$$
\begin{aligned}
& P P=O B G-\frac{\left(\sigma_{\max }\right)(1-U)\left(\frac{\frac{10^{6}}{D T}-\frac{10^{6}}{D T_{m l}}}{A}\right)^{(U / B)}}{\text { depth }} \text { and, } \\
& \sigma_{\max }=\left(\frac{\frac{10^{6}}{D T_{\min }}-\frac{10^{6}}{D T_{m l}}}{A}\right)^{(1 / B)}
\end{aligned}
$$

where;

$$
\begin{aligned}
& \text { PP = Pore Pressure Gradient (psi/ft,lb/gal, etc.), }(\mathrm{kPa} / \mathrm{m}, \mathrm{g} / \mathrm{cc} \text {, etc.) } \\
& \text { OBG = Overburden Gradient ( } \mathrm{psi} / \mathrm{ft}, \mathrm{lb} / \mathrm{gal} \text {, etc.), }(\mathrm{kPa} / \mathrm{m}, \mathrm{g} / \mathrm{cc} \text {, etc DT } \\
& =\text { Sonic travel time }(\text { microsec } / \mathrm{ft}, \mathrm{microsec} / \mathrm{m}, \mathrm{etc}) \\
& \text { DT }_{\mathbf{m l}}=\text { Sonic travel time corresponding to } \\
& \mathbf{A}, \mathbf{B}, \mathbf{U}=\text { Empirical values } \\
& \text { Vmax = The velocity at which unloading occurred for sediments buried at depths } \\
& \mathbf{d}_{\text {maxv }}=\text { Depth at which unloading has occurred } \\
& \text { depth }=\text { TVD in appropriate units }
\end{aligned}
$$

In this case, the vertical effective stress of the sediment will be less than it was in the past and in the so-called "Unloaded state".

To perform this analysis, it is necessary to know the sediment's previous maximum effective stress $\max _{\text {, }}$ and it is necessary to determine the effective stress behavior of the sediment "Unloading" velocity, which is determined by the unloading parameter, U. The value of ${ }_{\max }$ is calculated from the normal compaction response, the user defined value of, and the value of $U$ is determined empirically. 


\section{c. Fracture Gradient (FG) Prediction Calculation}

In predicting Fracture Gradient (FG) several methods can be used, including Eaton Method, Daines Method, Matthew \& Kelly Method, and Breckels Method.

\section{- Eaton's Method}

Fracture pressure is the pressure that forms the fracture when the minimum compressive stress and tensile strength are exceeded by the pore fluid pressure. Practically speaking, fracture pressure is the limit of pressure that a formation can withstand from a given column of mud.

Prediction of fracture pressure, LOT trend can be valid and representative using the Eaton calculation method.

$$
F G=P P+(O B G-P P)\left(\frac{v}{1-v}\right)
$$

where;

$$
\begin{aligned}
& \text { FG = Fracture Gradient }(\mathrm{psi} / \mathrm{ft} \text { or } \mathrm{lb} / \mathrm{gal}),(\mathrm{kPa} / \mathrm{m} \text { or g/cc) } \\
& \mathbf{P P}=\text { Pore Pressure Gradient }(\mathrm{psi} / \mathrm{ft} \text { or } \mathrm{lb} / \mathrm{gal}),(\mathrm{kPa} / \mathrm{m} \mathrm{or} \mathrm{g} / \mathrm{cc}) \\
& \begin{array}{ll}
\text { OBG } \quad=\text { Overburden Gradient (psi } / \mathrm{ft} \text { or } \mathrm{lb} / \mathrm{gal}),(\mathrm{kPa} / \mathrm{m} \text { org } / \mathrm{cc}) \\
\mathbf{v} \quad=\text { Poisson's Ratio (dimensionless) }
\end{array}
\end{aligned}
$$

\section{- Daine's Method (1982)}

Daine's method in predicting the Fracture Gradient by superposing the horizontal tectonic stress t to the Eaton equation. Expressing in terms of stress, as "the minimum stress in the borehole that must be resisted opening and extending the existing fault", which can be written in the following equation:

$$
{ }_{F G} \frac{\sigma l+\sigma\left(\frac{v}{1-v}\right)}{\text { depth }}+P
$$

where;

$$
\begin{array}{ll}
\sigma & =\text { vertical effective stress } \\
\sigma_{1} & =\text { superimposed tectonic stress } \\
\mathrm{V} & =\text { Eaton's Poisson's ratio } \\
\mathrm{P} & =\text { pore pressure }
\end{array}
$$

In determining the value of the effective pressure ratio (K), Daines uses an additional parameter to describe the lithological condition due to the influence of tectonic activity. For example, there are folds and faults. Therefore, the fracture pressure value obtained from the Daines method will depend on the lithology, depth, and tectonic activity.

\section{- Matthew \& Kelly Method}

The Matthew \& Kelly method is a Fracture Gradient predication method using a variable of "Matrix stress coefficient (Ki)", equivalent to the effective stress coefficient to calculate the fracture gradient of sedimentary formations:

$$
F G=P P+(O B G-P P) K_{i . .}
$$

where;

$\mathrm{FG}=$ Fracture Gradient (psi/ft atau lb/gal), $(\mathrm{kPa} / \mathrm{m}$ atau g/cc)

$\mathrm{PP} \quad=$ Pore Pressure (psi $/ \mathrm{ft}$ atau $\mathrm{lb} / \mathrm{gal}), \mathrm{kPa} / \mathrm{m}$ atau $\mathrm{g} / \mathrm{cc}$ )

OBG = Overburden Gradient (psi/ft atau lb/gal), $\mathrm{kPa} / \mathrm{m}$ atau $\mathrm{g} / \mathrm{cc}$ ) 
Evaluation of Mud Weight Using Safe Mud Window Concept Based on Well Log Data: A Case Study of Well OP002 in the North Sumatra Basin Area, Indonesia

$\mathrm{K}_{\mathrm{i}} \quad=$ Matrix Stress Coefficient(dimensionless)

\section{- Breckels Method}

The Breckels method is derived from fracture data (leak-off test) in the Gulf of Mexico (GoM), which is often used in calm tectonic areas such as the North Sea. In the Gradient Breckels fracture, abnormal pore pressures are taken into account.

$$
\begin{aligned}
& S_{3}=0.053 Z^{1.145}+0.46(P-P n) \text { untuk } Z \leq 3,3,500 \mathrm{~m} \\
& S_{3}=0.0264 Z-317+0.46(P-P n) \text { untuk } Z \leq 3,3,500 \mathrm{~m} .
\end{aligned}
$$

where;

$$
\begin{array}{ll}
\mathrm{S}_{3} & =\text { minimum horizontal stress (bar) } \\
Z & =\text { depth (meters) } \\
P & =\text { pore pressure (bar) } \\
P_{n} & =\text { normal pore pressure (bar) }
\end{array}
$$

\section{d. $S_{\text {hmin }}$ Prediction Calculation}

LOT, FPIT, and DFIT are useful methods for determining the minimum horizontal stress at any part of a borehole. However, the measured data are usually not available at the desired location and depth.

In addition, most of the LOT data provide only fracture initiation pressures or formation breakdown pressures and do not indicate fracture closure pressures (i.e., the minimum stress).

The micro-frac test can be performed while drilling, which provides real-time measurements of horizontal stress, but for very tight rocks, the micro-frac test may not crack the formation. Therefore, there are still challenges to determine and predict the minimum horizontal stress efficiently, routinely, and accurately (Zhang 2013).

In a normal faulting stress regime, the minimum horizontal stress is the minimum principal stress and can be calculated by assuming a uniaxial strain condition. For isotropic rocks and without the influence of tectonic stress effects, the minimum horizontal stress can be expressed as follows:

$$
S h \min =\frac{v}{(1-v)}(S v-\alpha P p)+\alpha P p
$$

where;

$$
\begin{aligned}
& \text { Sh }=\text { minimum horizontal stress } \\
& \text { Sv } \quad=\text { overburden stress } \\
& \mathrm{V}=\text { = Poisson's ratio } \\
& \mathrm{Pp} \quad=\text { pore pressure } \\
& \alpha=\text { Biot's coefficient }
\end{aligned}
$$

Equation-6 shows that the minimum horizontal stress is highly dependent on overburden stress and pore pressure.

Case in point for testing the minimum horizontal stress of 5 wells in the Travis Peak formation using the mini-frac and other tests (Zhang 2019).

Figure 5 shows a plot of measured and calculated pore pressure, overburden, minimum horizontal stress measured and calculated. This shows that the minimum horizontal stress calculated from the uniaxial stress model (Equation-9) gives a very reasonable value. 


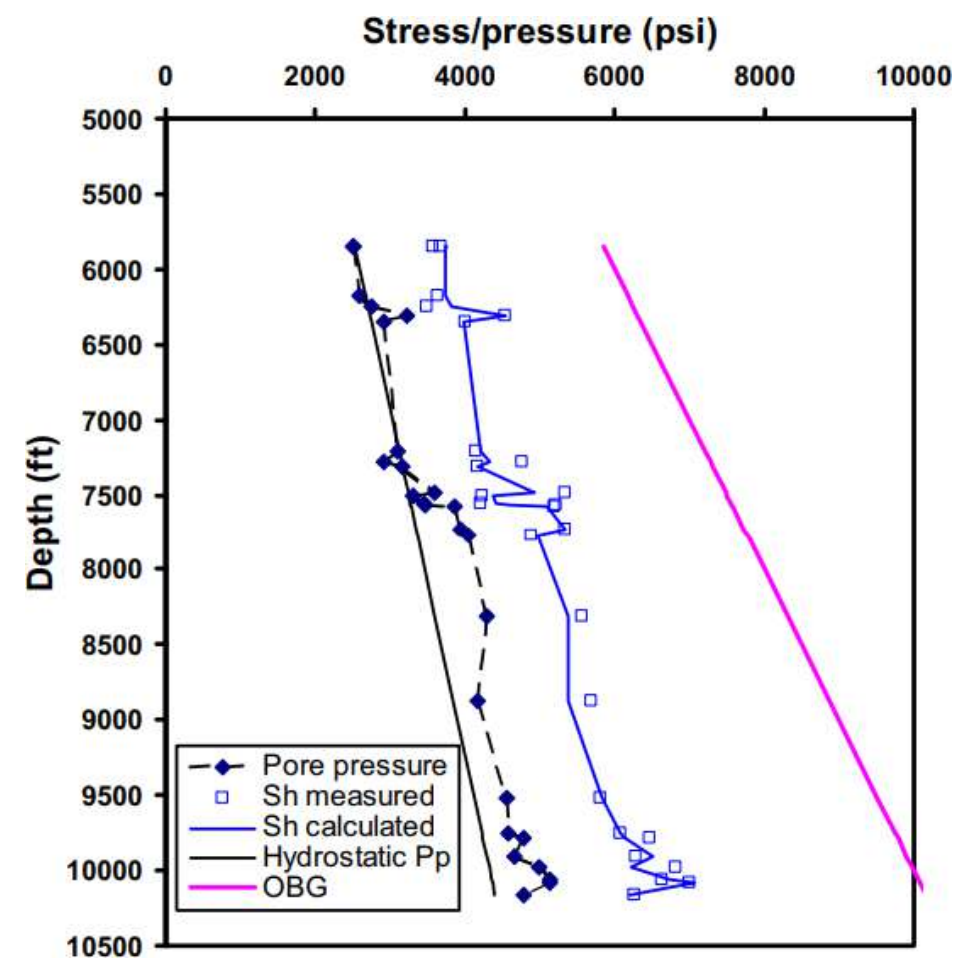

Figure 5. Minimum horizontal stress is calculated with Equation- 9 , and constant $=0.95$ using data from Whitehead, Hunt, and Holditch (Zhang 2019)

\section{e. S Hmax $_{\text {Prediction Calculation }}$}

The value and direction of maximum horizontal stress need to be known, especially for directional drilling, because drilling directed to maximum horizontal stress should be avoided. Calculation of maximum horizontal stress can be calculated by the equation:

$$
S_{H \max } S_{h \min } k \quad\left(\begin{array}{lll}
O B G & S_{h \min }
\end{array}\right)
$$

where;

$\mathrm{k}$ is the tectonic factor, according to Zoback (2007) the value of $\mathrm{k}=0.5$ when the fault that occurs around the borehole is a normal fault and $\mathrm{k}=1.5$ if it is a reverse fault.

$$
\begin{aligned}
& \mathrm{S}_{\mathrm{H} \max } \quad=\text { Maximum Horizontal Stress, psi } \\
& \mathrm{S}_{\mathrm{hmin}}=\text { Minimum Horizontal Stress, psi } \\
& \mathrm{k} \quad=\text { tectonic factor, dimensionless } \\
& \mathrm{OBG}=\text { Gradient Overburden, psi }
\end{aligned}
$$

\section{f. SFG Prediction Calculation}

Determination of Shear Failure Gradient using Modified Lade Method. To determine the value of the share failure gradient or shear failure stress with this modified lade, it can be calculated using the equation:

$$
S F G=27-\eta L-\frac{\left(I_{1}^{\prime}\right) 3}{I_{3}^{\prime}}
$$

where; 


$$
\begin{aligned}
& I_{1}^{\prime}=(S v+S)+\left(S H_{\text {max }}+S\right)+\left(S h_{\text {min }}+S\right) \\
& I_{3}^{\prime}=(S v+S) \times\left(S H_{\text {max }}+S\right) \times\left(S h_{\text {min }}+S\right) \\
& S=\frac{C S}{\tan \phi} \\
& \eta_{L}=\frac{4(\tan \phi) 2 \times(9-7 \sin \phi)}{(1-\sin \phi)}
\end{aligned}
$$

where;

$$
\begin{aligned}
& \mathrm{S}_{\mathrm{hmin}}=\text { Gradien Tekanan Rekah, ppg } \\
& \mathrm{S}_{\mathrm{H} \max } \quad=\text { Maximum Horizontal Stress Gradient,ppg } \\
& \begin{array}{ll}
\mathrm{SFG}=\text { Shear } & \text { Failure Gradient, ppg } \\
\Phi & =\text { Internal Friction Angle, degree } \\
\mathrm{CS} & =\text { Cohesive Strength, } \mathrm{MPa} \\
\mathrm{Sv} & =\text { Gradien tekanan overburden,ppg }
\end{array}
\end{aligned}
$$

\section{STUDY AREA AND RESEARCH METHOD}

Well OP-002 is located in the North Sumatra Basin, where the well OP-002 is an exploration well with a reservoir target of shale rock in the Belumai Formation which is a gas reservoir. This well was drilled on 4 October 2016 reaching a final depth of $3796.1 \mathrm{~m}$ TVD on 22 February 2017. The location of well OP-002 can be seen in Figure 1.

The regional stratigraphy of the North Sumatra Basin from youngest to oldest (Barliana et al 1999) can be seen in Figure 2 as follows:

- Keutapang Formation (o - 404m).

The Keutapang Formation consists of fine-grained sandstone and shale.

- Baong Formation (404 - 3254.6m).

The Baong Formation is dominated by shale with sandstone intercalation. At this depth interval, there is a Top BRS formation at a depth of $1357.6-1499.1 \mathrm{~m}$ with a lithology that is dominated by shale with sandstone and carbonate intercalation. There is a Top Gebang formation of 1499.1 - $2615.6 \mathrm{~m}$ with a lithology that is dominated by shale with insertions of sandstone, siltstone, and carbonate.

- Belumai Formation (3254.6-3520.4m).

The Belumai Formation consists of shale and thick layers of limestone and sandstone inserts.

- Bampo Formation (3520.4 - 3796.1m).

The Bampo Formation consists of shale with little carbonate rock intercalation. 


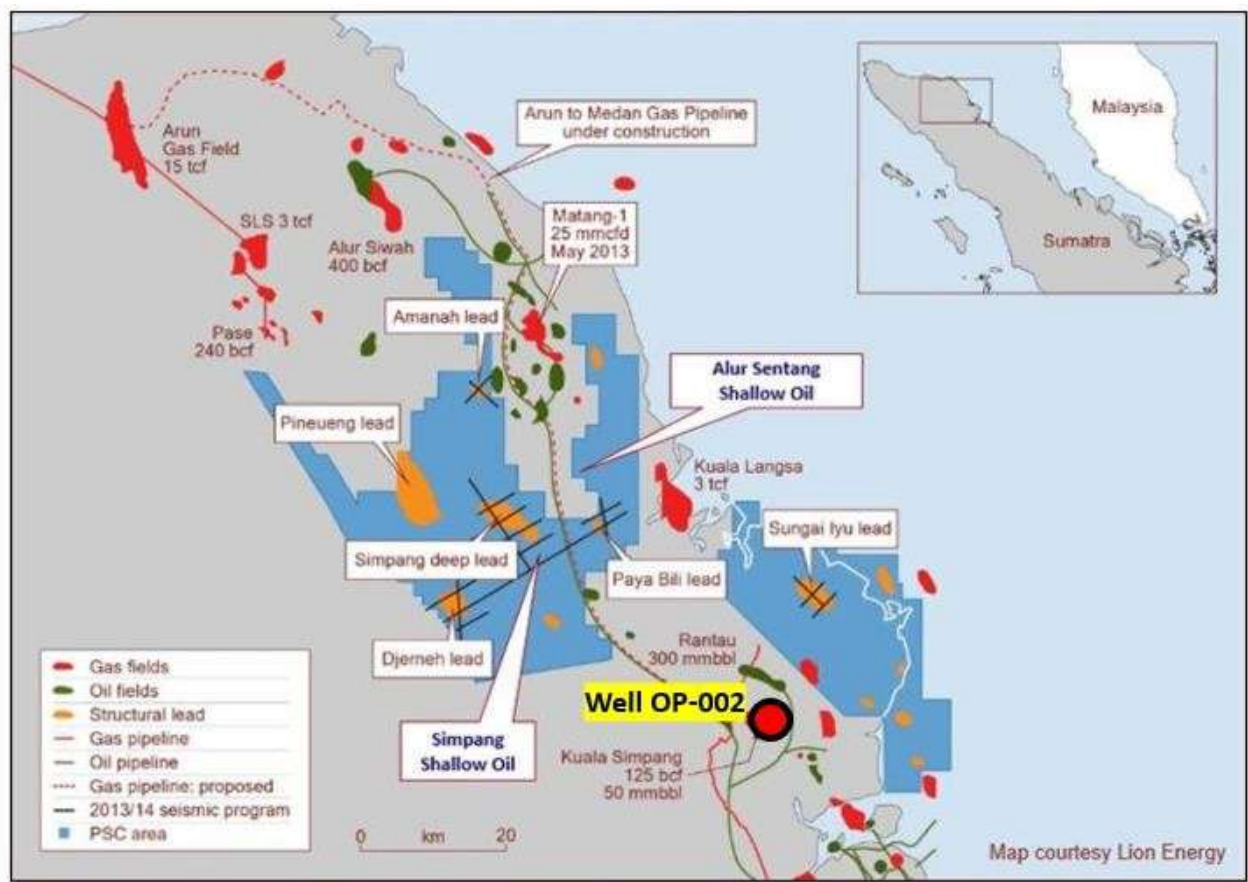

Figure 1.Location Map ofWellOP-002 (SeismicAtlas2008)

The lithology penetrated in the drilling operation of well OP-002 is dominated by shale rock types, with some formations found in sandstone and carbonate rock lithology.

Figure 4 shows the research workflow, explaining starting from collecting data, determining the overpressure mechanism, method selection, pore pressure validation, fracture pressure estimation, fracture pressure validation, horizontal stress \& shear failure gradient determination, and the final result is a 1D geomechanical model (geopressured model) with a safe mud window.

\section{LITHOSTRATIGRAPHY NORTH SUMATRA BASIN}

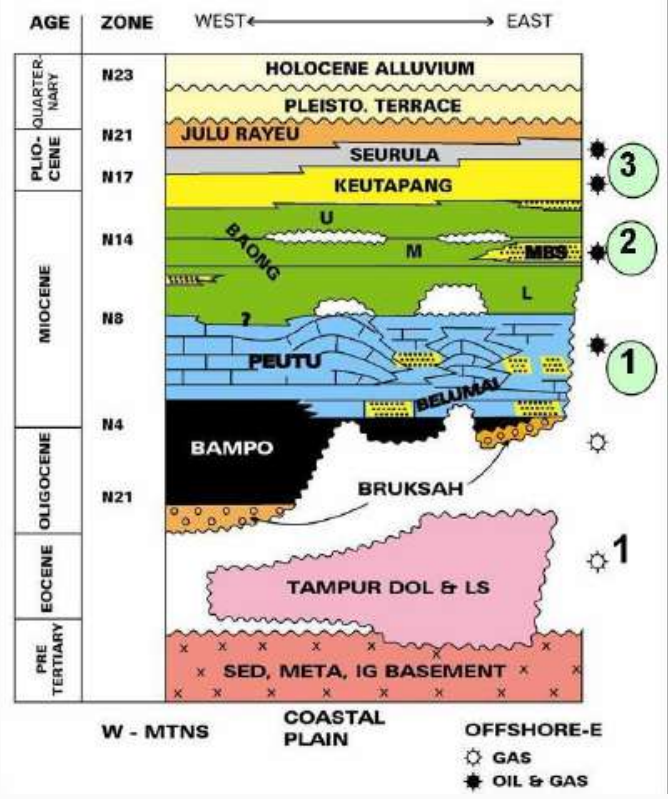

Figure 3. Stratigraphy of the North Sumatra Basin showing the order of deposition from the oldest to the youngest and from the west to the east (Barliana et al 1999) 


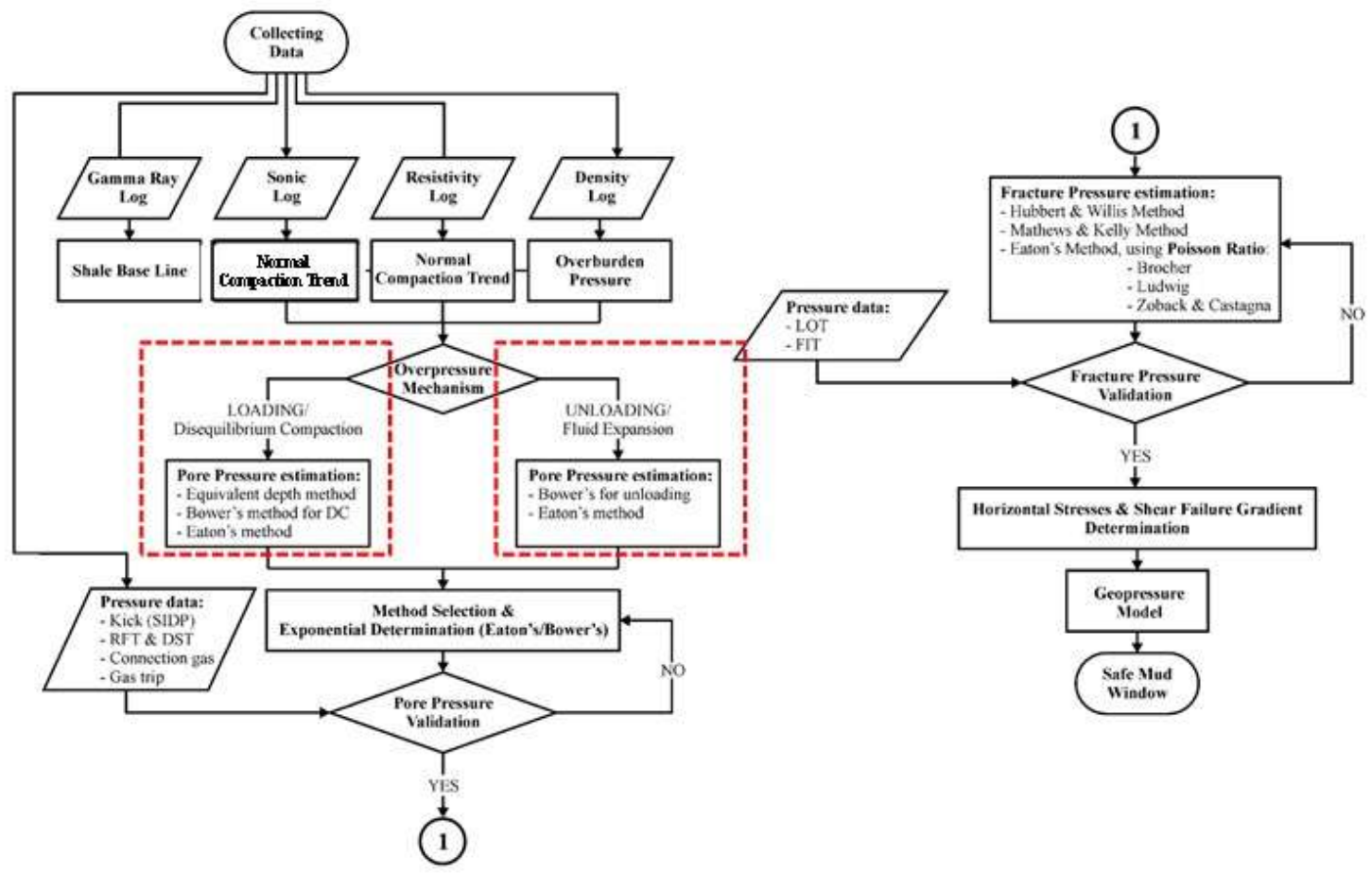

Figure 4. Research Flowchart (Wibowo 2020)

\section{FINDING AND DISCUSSION}

The safe mud window is the result of the calculation of the subsurface pressure used to determine the optimal mud weight value so that drilling is carried out smoothly. For safe mud window modeling, log data are needed, namely gamma ray $\log$, density log, and sonic log. From these data, overburden pressure, pore pressure, formation fracture pressure, minimum horizontal stress, maximum horizontal stress, and shear failure gradient can be calculated.

After determining the safe mud window, an analysis of the mud weight related to the drilling problem was carried out at the depth interval of the penetrated formation. If the value of the mud weight is below the value of the shear failure gradient, then caving will occur, and if it is above the minimum horizontal stress, there will be a loss of circulation. To overcome this problem, an evaluation of the mud weight is carried out, so that it remains in the safe mud window interval, or in other words, the value of the mud weight is between the shear failure gradient and the minimum horizontal stress.

\section{Determination of Overburden Gradient}

The calculation of overburden pressure (vertical stress) must first be done, because it is a parameter that is always used in the next calculation stage, namely the calculation of pore pressure, fracture pressure, Shmin, SHmax, and shear failure gradient.

The calculation of overburden pressure requires density data for each depth, while the available density data is limited. To interpret the rock density at a depth for which there is no log data, the Gardner equation is used, which results are calibrated with density log data so that density data is combined using Gardner and density data log, which produces RHOB Composite which represents the log data in each depth and the data can be used as bulk density in the overburden gradient calculation process as presented in Figure 6. 


\section{Determination of Pore Pressure}

The determination of pore pressure should be matched with the well pressure data of OP-002, which is $16 \mathrm{ppg}$ (maximum pressure in the overpressure zone). The method used in calculating pore pressure is Eaton and Bower. Both have results that match with the pressure data, to calibrate the results, it is necessary to look at the MWactual data used.

The NCT withdrawal is based on an area that has normal pressure, if the log value is close to the NCT data then the area has normal pressure, if the sonic log value is above the NCT then the area is an overpressure area. Figure 7 shows the results of Bower's calculations, where the blue color is the DT value, while the green color is the normal result of the compaction trend using Bower's method. The results of the calculated pore pressure prediction using the Eaton method are shown in Figure 8.

\section{Geomechanics Parameter Determination}

After calculating the pore pressure using the Eaton method, the next step is to calculate the fracture gradient. But before we calculate it, we must first calculate some geomechanics parameters.

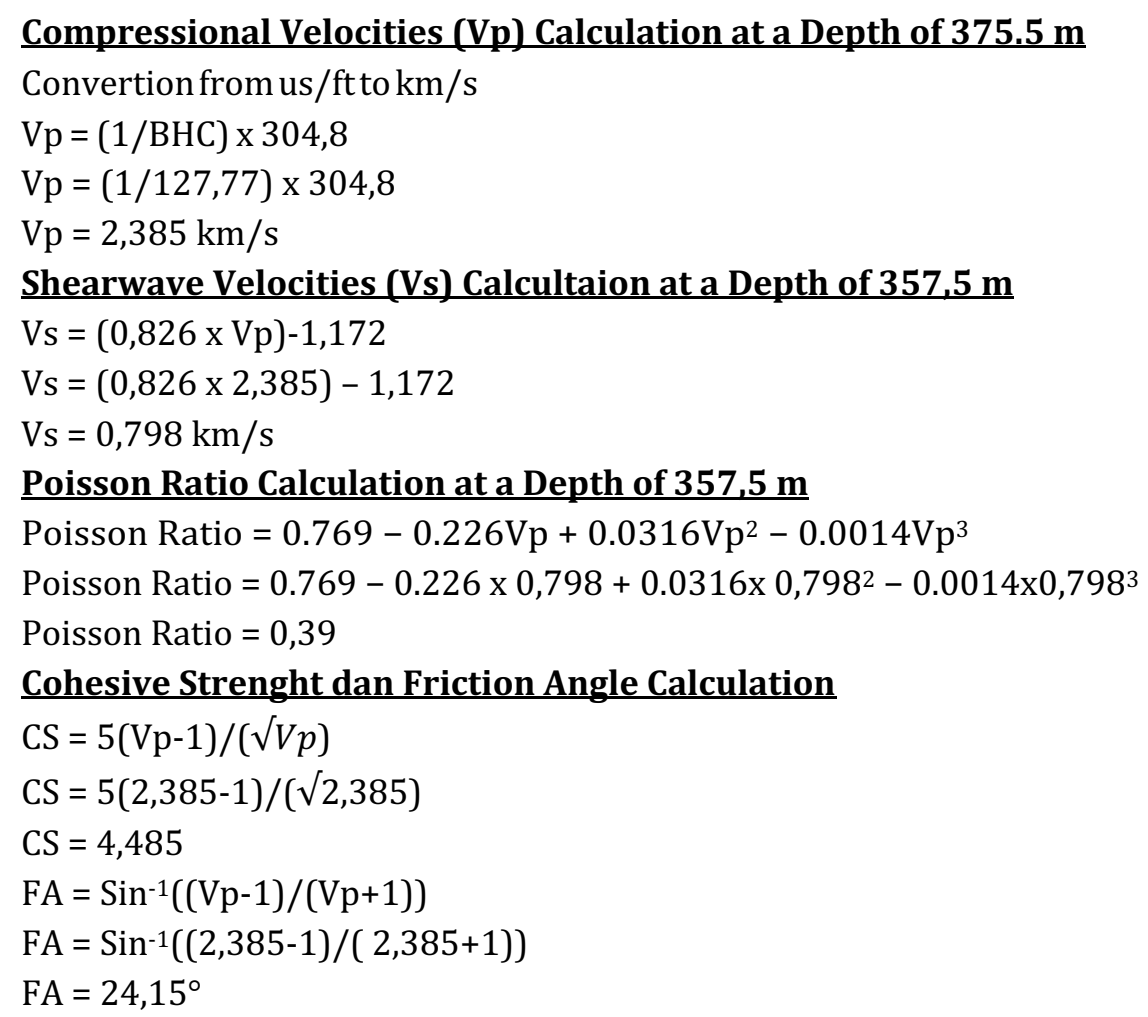

\section{Determination of Fracture Gradient}

After calculating the geomechanics parameters using several methods, the next step is to calculate the fracture gradient. To calculate the fracture gradient, several methods are used, namely Eaton, Mathews \& Kelly, and Hubbert \& Willis. From these several equations, the results are compared for the results that are closest to the LOT data is the method that will be used in calculating the fracture gradient in the Mathews \& Kelly of well OP-002 as presented in Figure 9.

In this case, because the fracture gradient calculation using the Mathews \& Kelly method is closest to the LOT value, the fracture gradient equation from the Mathews \& Kelly method will be used in the PPFG model, wherein the fracture gradient equation using the Mathews \& Kelly method there are pore pressure and overburden pressure parameters. Figure 10 shows the fracture gradient using the Mathews \& Kelly method. 
Evaluation of Mud Weight Using Safe Mud Window Concept Based on Well Log Data: A Case Study of Well OP002 in the North Sumatra Basin Area, Indonesia

\section{Determination of Minimum and Maximum Horizontal Stress}

After calculating the fracture pressure, the next step is to determine the minimum horizontal stress and maximum horizontal stress. To determine the minimum horizontal stress and maximum horizontal stress should be known the fault type in the North Sumatra Basin, where the type of fault in the North Sumatra Basin is strike-slip, so the value of SHmax $>\mathrm{Sv}>\mathrm{SHmin}$.

Based on the type of strike-slip fault, the calculation results in Figure 11 show that it is true that the North Sumatra Basin is strike-slip because the value of SHmax $>$ Sv $>$ SHmin. Parameters of minimum horizontal stress and maximum horizontal stress are very important for calculating the next parameter, namely shear failuregradient.

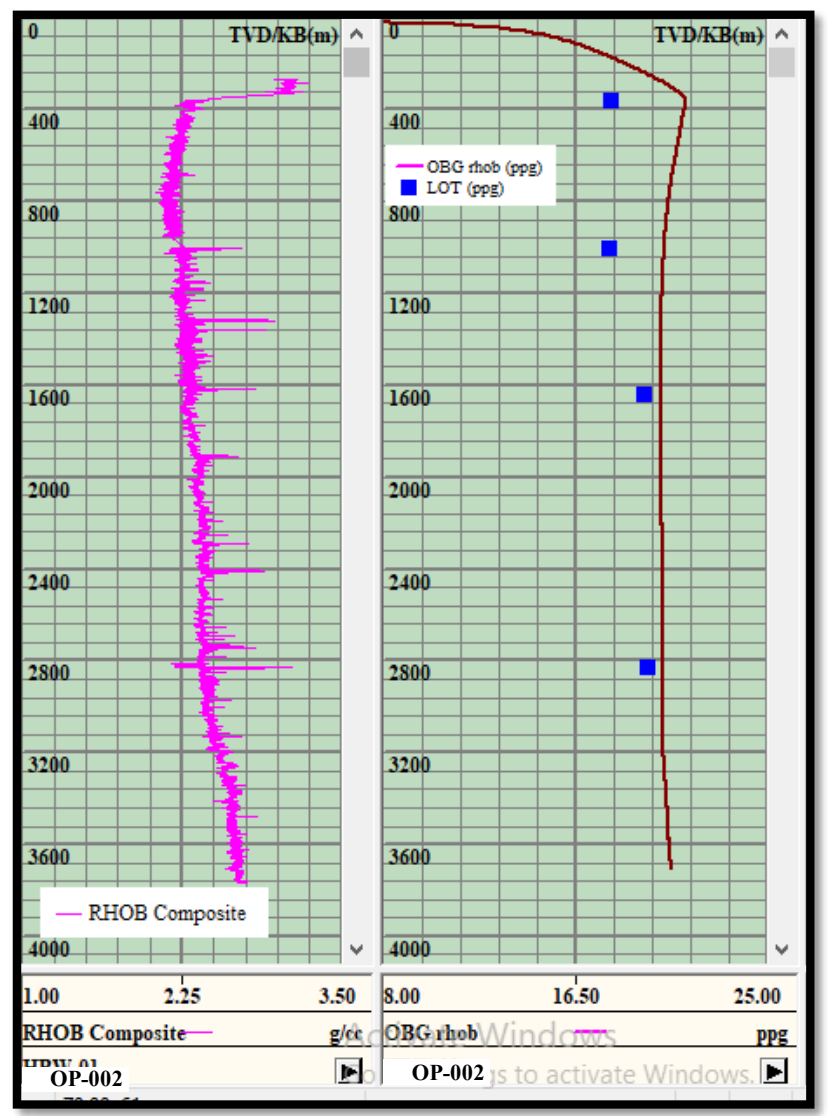

Figure 6. Overburden Gradient Results 
RSF Conference Series: Engineering and Technology

Vol. 1 (1), 248-266

Evaluation of Mud Weight Using Safe Mud Window Concept Based on Well Log Data: A Case Study of Well OP002 in the North Sumatra Basin Area, Indonesia

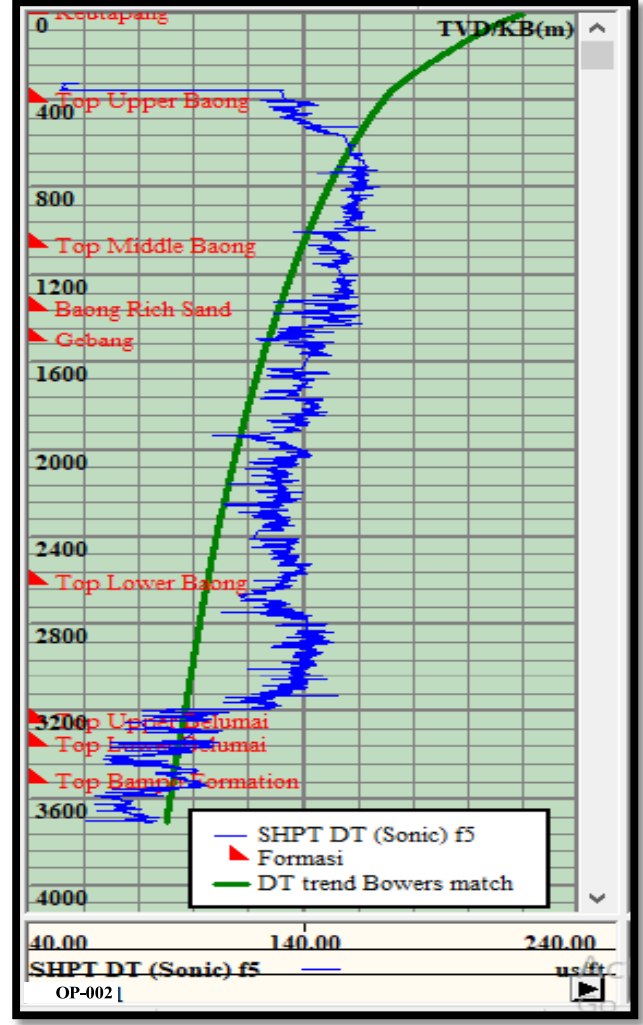

Figure 7. Normal trend withdrawal results on Sonic Log

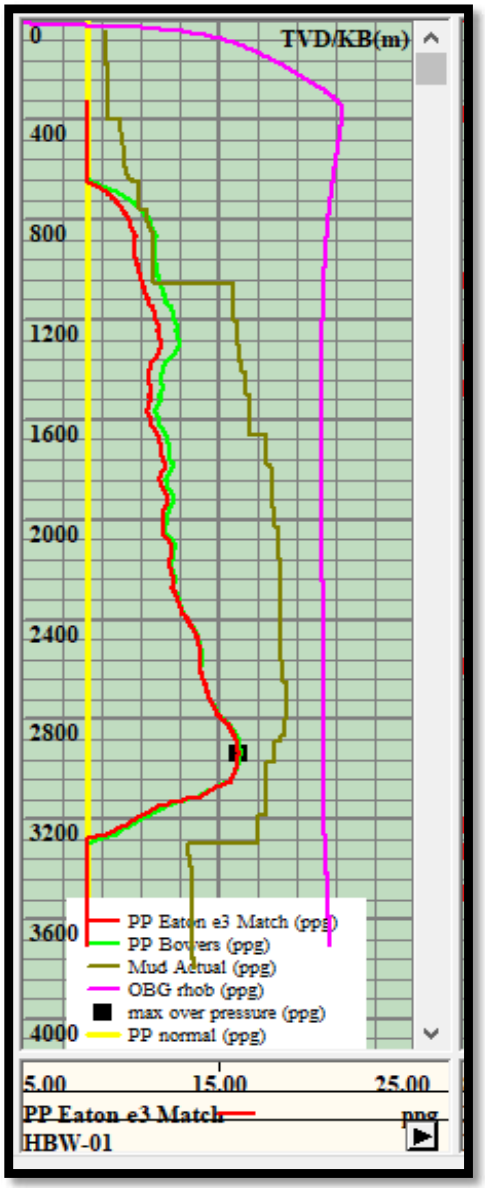


RSF Conference Series: Engineering and Technology

Vol. 1 (1), 248-266

Evaluation of Mud Weight Using Safe Mud Window Concept Based on Well Log Data: A Case Study of Well OP002 in the North Sumatra Basin Area, Indonesia

Aris Buntoro, Basuki Rahmad, Allen Haryanto Lukmana, Dewi Asmorowati

Figure 8. Pore Pressure Results using the Eaton Method

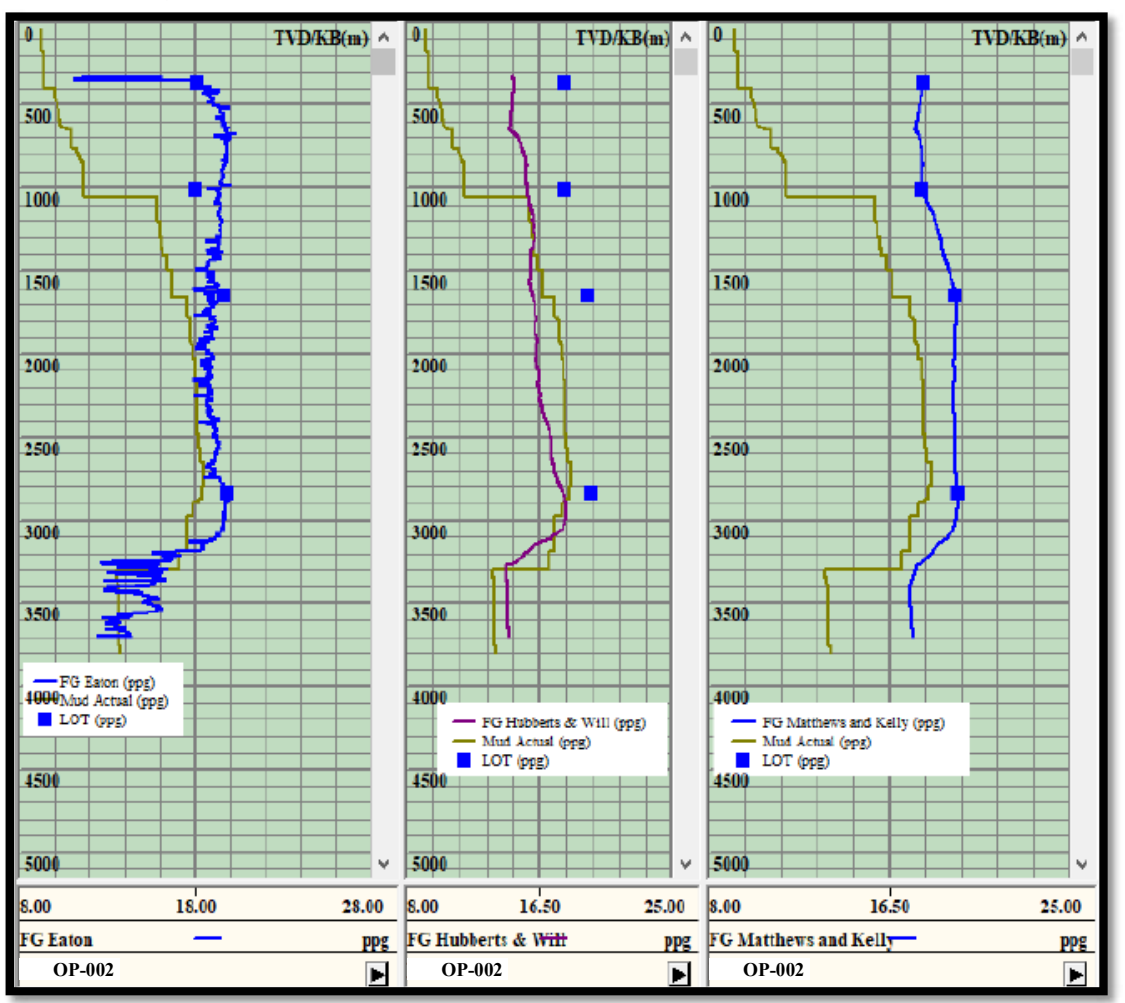

Figure 9. Validation of Fracture Pressure Results with Several Methods using LOT data

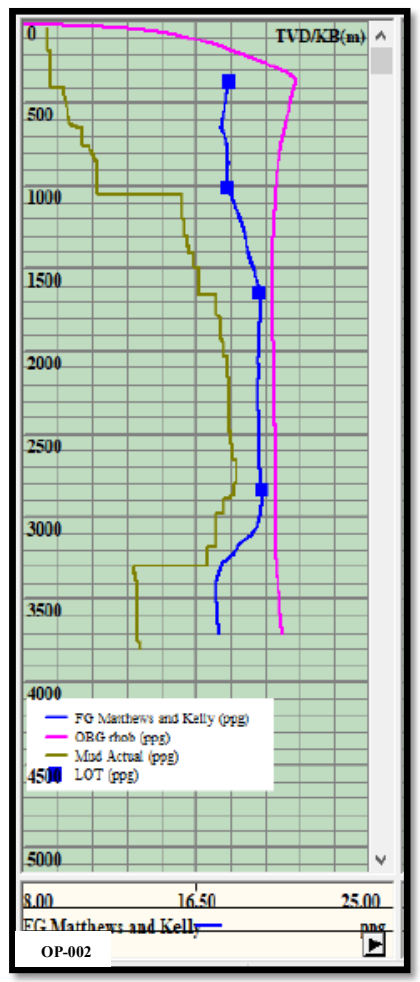

Figure 10. Fracture Gradient Results using Mathews \& Kelly Method 


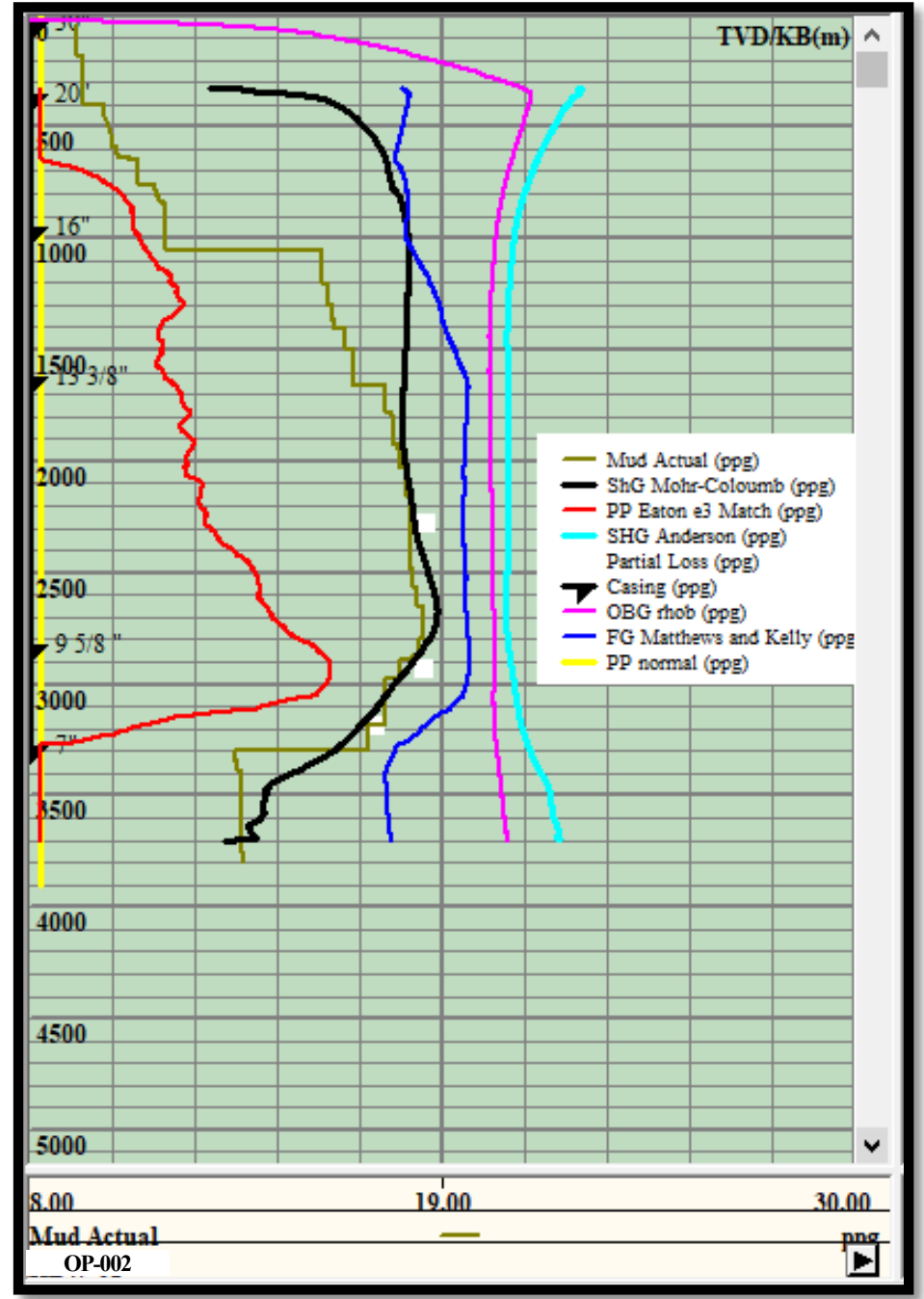

Figure 11. Results of Shmin Mohr-Columb Friction and SHmax using Anderson Method

\section{Determination of Shear Failure Gradient}

The next step is to determine the value of the Shear Failure Gradient, in calculating the shear failure gradient. The method used is Modified Lade Criterion because this method takes into account 3 principal stresses, namely overburden stress, minimum horizontal stress, and maximum horizontal stress. In addition, this method also uses two geomechanical parameters, namely friction angle, and cohesive strength. The calculation results can be seen in Figure 12. 
Evaluation of Mud Weight Using Safe Mud Window Concept Based on Well Log Data: A Case Study of Well OP002 in the North Sumatra Basin Area, Indonesia

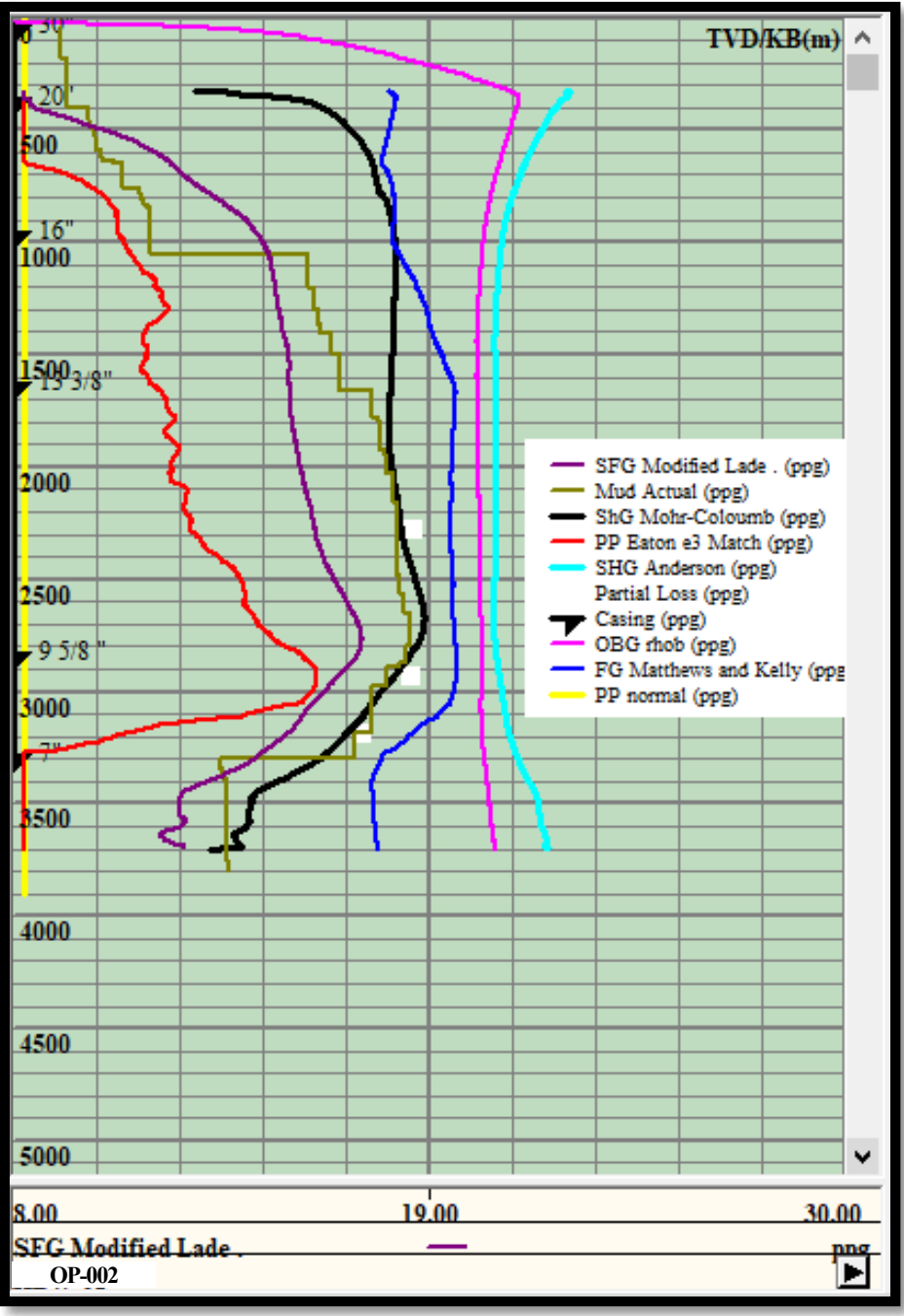

Figure 12. Results of Shear Failure Gradient using Modified Lade Method

Determination of Shear Failure Gradient using the modified Lade method has advantages, where this method can be carried out in all areas, and considers the stress principle that has been carried out in the previous calculation, namely overburden pressure, minimum horizontal stress, and maximum horizontal stress.

\section{Evaluation of Mud Weight Based on Drilling Problems in Well OP-002}

At this stage, an evaluation of the use of the mud weight is carried out, whether it is in accordance with the safe mud window, and identifies the causes of problems that occur in the drilling operation of well OP-002. If the mud weight design is not in accordance by the safe mud window, drilling problems such as caving and partial loss will occur during the drilling operation as shown in Table 2.

The mud weight used during the drilling operation is not in accordance by the safe mud window, resulting in partial loss and caving problems as presented in Figure 13. 
RSF Conference Series: Engineering and Technology

Vol. 1 (1), 248-266

Evaluation of Mud Weight Using Safe Mud Window Concept Based on Well Log Data: A Case Study of Well OP-

002 in the North Sumatra Basin Area, Indonesia

Aris Buntoro, Basuki Rahmad, Allen Haryanto Lukmana, Dewi Asmorowati

Table 2. Hole Problems in Well OP-002

\begin{tabular}{|c|c|c|c|}
\hline $\begin{array}{c}\text { Hole } \\
\text { Problems }\end{array}$ & $\begin{array}{c}\text { Depth Interval } \\
\text { (m) }\end{array}$ & Formation & Lithology \\
\hline Caving & $500-1050$ & $\begin{array}{c}\text { Keutapang-Top Middle } \\
\text { Baong }\end{array}$ & $\begin{array}{c}\text { Shale, } \\
\text { Sandstone, } \\
\text { Carbonate }\end{array}$ \\
\hline Caving & $1050-1650$ & Middle Baong - Gebang & $\begin{array}{c}\text { Shale, Sandstone, } \\
\text { Carbonate }\end{array}$ \\
\hline Partial loss & 2877,35 & Top Gebang & Shale \\
\hline Partial loss & 2932,277 & Lower Baong & Shale \\
\hline Partial loss & 3181,927 & Lower Baong & Shale \\
\hline
\end{tabular}
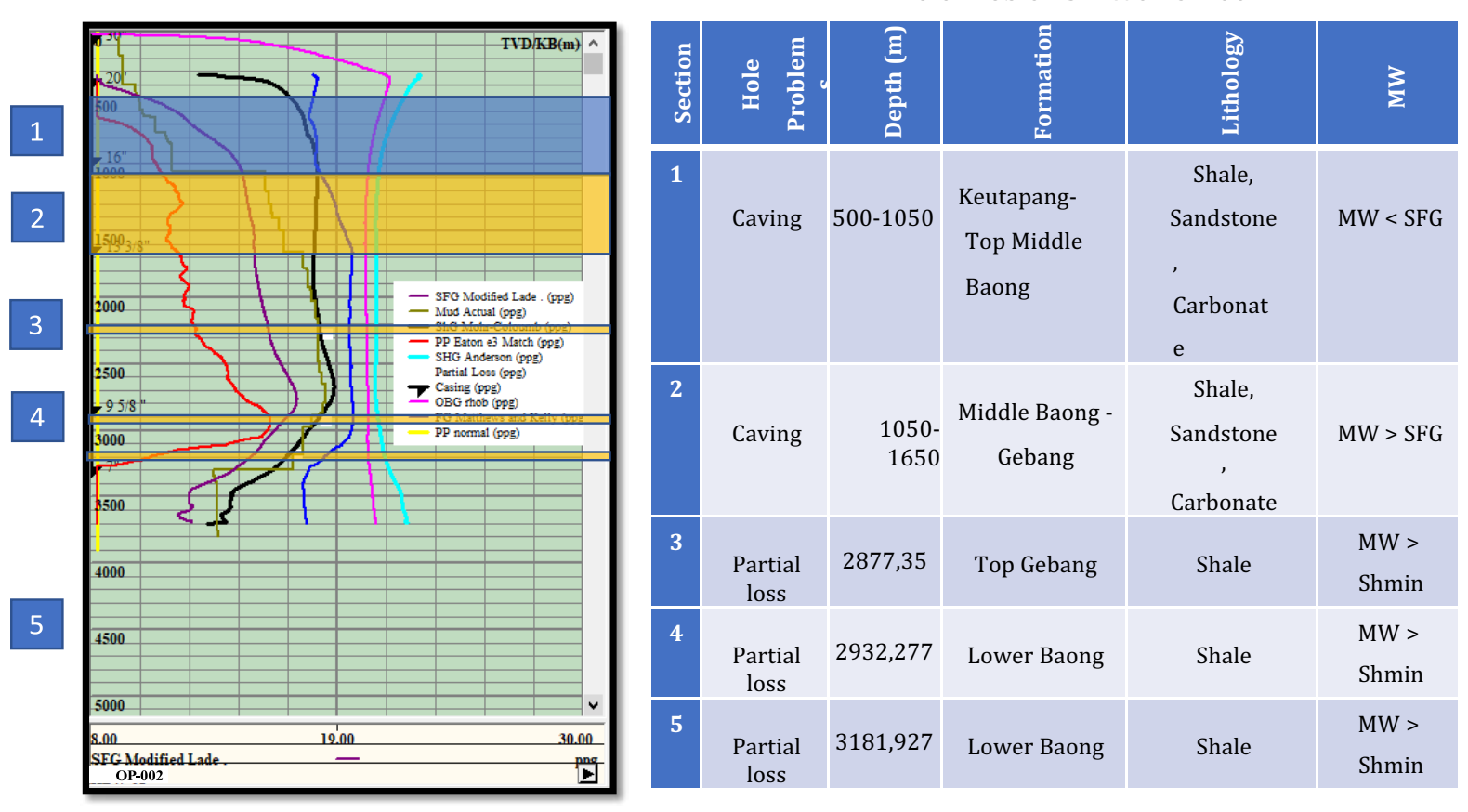

Figure 13. Mud Weight used when drilling operation of well OP-002

Based on the safe mud window that has been built at a depth of $500-1050 \mathrm{~m}$ caving occurs, because the value of the mud weight used is smaller than the shear failure gradient, so caving occurs at a depth of 2887, 2945, and $3186 \mathrm{~m}$, and it can be seen that the actual mud weight is above the horizontal minimum stress. This indicates that the weight of the mud used exceeds the minimum horizontal stress in the formation, resulting in the partial loss. In accordance by the conditions that occurred in well OP- 002, where at a depth of 2887,2945 , and $3186 \mathrm{~m}$ there was a partial loss problem. The value of the mud weight used during the drilling operation can be seen in Table 3. 
RSF Conference Series: Engineering and Technology

Vol. 1 (1), 248-266

Evaluation of Mud Weight Using Safe Mud Window Concept Based on Well Log Data: A Case Study of Well OP002 in the North Sumatra Basin Area, Indonesia

Aris Buntoro, Basuki Rahmad, Allen Haryanto Lukmana, Dewi Asmorowati

Table 3. Mud Weight actual in drilling operation of well OP-002

\begin{tabular}{|c|c|c|}
\hline $\begin{array}{c}\text { Depth Interval } \\
\text { (m) }\end{array}$ & $\begin{array}{c}\text { Borehole Diameter } \\
\text { (inch) }\end{array}$ & $\begin{array}{c}\text { Density ( } \\
\text { ppg) }\end{array}$ \\
\hline $0-36$ & 30 & - \\
\hline $36-354,2$ & 20 & $9,2-9.4$ \\
\hline $354,2-948$ & 16 & $9,99-11,66$ \\
\hline $948-1619$ & $133 / 8$ & $15,8-16,66$ \\
\hline $1619-2829$ & $95 / 8$ & $17,49-18,49$ \\
\hline $2829-3281$ & 7 & $17,07-18,24$ \\
\hline $3281-3800$ & & $13,49-13,74$ \\
\hline
\end{tabular}

\section{Determination of Optimal Mud Weight Based on Safe Mud Window}

To overcome the problems that occur, it is necessary to evaluate the mud weight used, namely the value of the mud weight must be greater than the shear failure gradient, and less than the minimum horizontal stress, so that caving does not occur, and partial loss. For planning Mud Weight using a safe mud window approach, it is expected to minimize problems during drilling. The recommended use of mud weight can be seen in Figure 14. The recommended mud weight value is presented in Table 4.

Table 4. Mud Weight Recommended for drilling operation of well OP-002

\begin{tabular}{|c|c|c|}
\hline $\begin{array}{c}\text { Depth Interval } \\
(\mathrm{m})\end{array}$ & $\begin{array}{l}\text { Borhole Diameter } \\
\text { (inch) }\end{array}$ & $\begin{array}{c}\text { Density } \\
\text { (ppg) }\end{array}$ \\
\hline $0-36$ & 30 & - \\
\hline $36-354,2$ & 20 & $9,2-9.4$ \\
\hline $354,2-948$ & 16 & $\begin{array}{c}14,49- \\
15,33 \\
\end{array}$ \\
\hline $948-1619$ & $\begin{array}{c}13 \\
3 / 8 \\
\end{array}$ & $\begin{array}{c}15,45- \\
17,65 \\
\end{array}$ \\
\hline $1619-2829$ & $95 / 8$ & $\begin{array}{c}17,36- \\
17,76 \\
\end{array}$ \\
\hline $2829-3281$ & 7 & $16,57-16,7$ \\
\hline $\begin{array}{l}3281- \\
3796,1\end{array}$ & & $\begin{array}{c}13,49- \\
13,74\end{array}$ \\
\hline
\end{tabular}




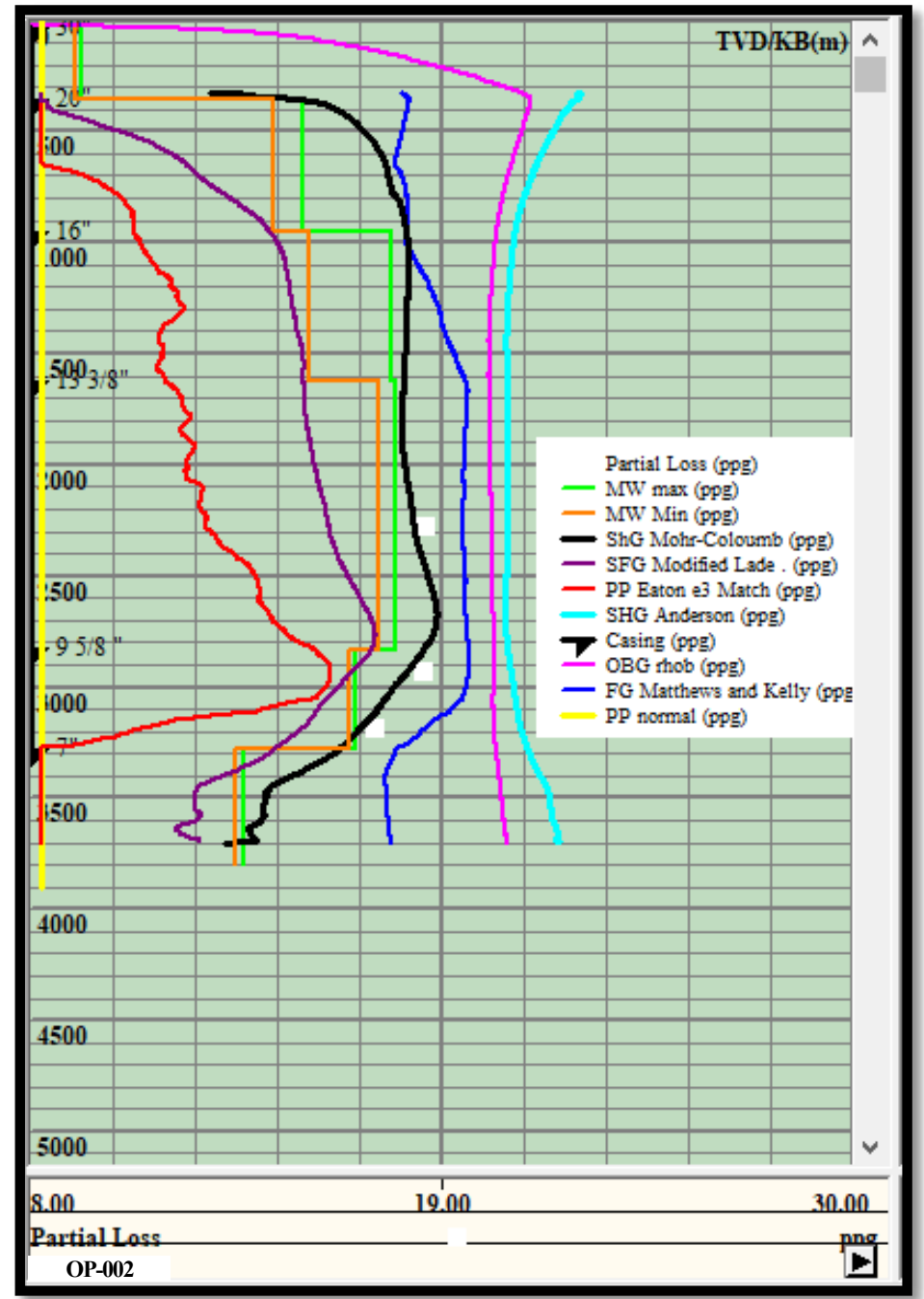

Figure 14. Mud Weight Recommended on Well OP-002

\section{CONCLUSION AND FURTHER RESEARCH \\ Conclusion}

1. The drilling operation of well OP-002 encountered caving problems at a depth interval of 500 - 1050 m (hole trajectory 16" and 13 3/8") due to the dynamic MWactual < SFG. To overcome this problem, the mud weight must be changed, namely on the hole trajectory 16 " to 14.49 -

$15.33 \mathrm{ppg}$, and the hole trajectory $133 / 8$ " to $15.45-17.65 \mathrm{ppg}$.

2. In section 2 caving problems occur at depth intervals of $1050-1650 \mathrm{~m}$, but the dynamic MWactual condition is greater than SFG, so the caving problem in this section is estimated due to drilling through the brittle formation.

3. In sections 3, 4, and 5 partial loss occurs because the dynamic MWactual value is greater than the Shmin value, which causes fracture formation and partial loss. To overcome this problem, the mud weight must be changed, namely on the hole trajectory $95 / 8$ " to $17.36-17.76 \mathrm{ppg}$, and the hole trajectory 7 " to $16.57-16.7 \mathrm{ppg}$.

4. Range mud weight is an MWstatic and MWdynamic limit, where the MWstatic value is not less than the lowest MWrecommendation value and MWdynamic is not higher than the highest MWrecommendation. 


\section{Further Research}

1. In Section 2 at a depth interval of 1050 - 1650 m even though the MWactual dynamic is $>$ SFG, caving problems occur which are thought to be due to drilling through a brittle formation.

2. To ensure that brittle formation does not occur at a depth interval of $1050-1650 \mathrm{~m}$, it is recommended that further research of mineralogical analysis (XRD) be carried out.

\section{Acknowledgments}

The author would like to thank LPPM "Veteran" Yogyakarta which has facilitated the applied research and Exploration Drilling of PT. Pertamina EP for contributing data and permission for publication.

\section{Conflicts of Interest}

The authors declare no conflict of interest regarding the publication of this paper.

\section{REFERENCES}

Barliana et al. 1999. "Changing Perceptions of a Carbonate Gas Reservoir: Alur Siwah Field, Aceh Timur, Sumatra." Indonesian Petroleum Association.

Basuki, Don. 2017. "Geopressure Prediction." in Workshop Pertamina (Persero).

Eaton, Ben A. 1975. "The Equation for Geopressure Prediction from Well Logs." SPE Annual Technical Conference and Exhibition. doi: 10.2118/5544-MS.

Hottman, G. E., and R. K. Johnson. 1965. "Estimation of Formation Pressures from Log-Derived Shale Properties." SPWLA 6th Annual Logging Symposium 19652:717-22.

Matthews, W.R. and Kelly,J.1967. "How to PredictFormation Pressure and Fracture Gradient.” Oil and Gas Journal, 65, 92-1066.

McClendon, Rehmand. 1971. "Measurement of Formation Pressure from Drilling Data." SPE Annual Technical Conference and Exhibition 3601.

Pennebaker. 1968. "An Engineering Interpretation of Seismic Data." SPE Annual Technical Conference and Exhibition 2165.

Seismic Atlas. 2008. "Compilation of Seismic Images of Geological Features in Southeast Asia Basins, Related to Ydrocarbon Potential of This Region. Countries Covered in This Atlas: Indonesia, Malaysia, Brunei, Philippines, Thailand, Vietnam."

Wibowo, H. B. 2020. "Evaluasi Mud Weight Pada Pemboran Sumur HBW-1 Dengan Safe Mud Window Concept." Thesis, Teknik Perminyakan, FTM, UPN "Veteran" Yogyakarta.

Zamora, Mario. 1974. "Practical Analysis of Drilling Mud Flow in Pipes and Annuli." SPE Annual Technical Conference and Exhibition SPE-4976-M.

Zhang, Jincai. 2013. "Borehole Stability Analysis Accounting for Anisotropies in Drilling to Weak Bedding Planes." International Journal of Rock Mechanics and Mining Sciences 60:160-70. doi: 10.1016/j.ijrmms.2012.12.025.

Zhang, Jincai. 2019. Applied Petroleum Geomechanics.

Zoback, Mark. 2007. "Reservoir Geomechanics." in Cambridge University Press. 